\title{
ANALISIS TREND PERAMALAN EFEKTIVITAS PENDAPATAN PAJAK KENDARAAN BERMOTOR (PKB) DAN BEA BALIK NAMA KENDARAAN BERMOTOR (BBN-KB) DI DISPENDA PROVINSI BENGKULU TAHUN 2010-2014
}

\author{
Karona Cahya Susena \\ Nurzam \\ Dosen Fakultas Ekonomi Universitas Dehasen Bengkulu
}

\begin{abstract}
ABSTRAK
Karona Cahya Susena, Nurzam: Tujuan penelitian ini untuk mengetahui trend efektivitas pendapatan pajak kendaraan bermotor dan pendapatan bea balik nama kendaraan bermotor di DISPENDA provinsi bengkulu. Penelitian ini meupakan Analisis Deskriptif dengan Sampel yang digunakan dalam penelitian ini adalah Data Pajak kendaraan bermotor dan bea balik nama kendaraan bermotor, dan Data Pendapatan Asli Daerah Provinsi Bengkulu tahun 2010-2014. Metode Least Square digunakan untuk peramalan.

Hasil dari penelitian ini menggambarkan efektivitas realisasi pendapatan PKB dan BBN-KB. Sama-sama terjadai pada tahun 2011 sebesar 122,26\%, dan 129,42\%. Hasil peramalan PKB pada tahun 2015 sebesar Rp 194.525.355.399 diramalkan meningkat pada tahun 2017 menjadi sebesar 230.315.333.298. Hasil peramalan BBN-KB tahun 2015 pendapatan BBN-KB sebesar Rp 192.990.945.600 diramalkan meningkat pada tahun 2017 menjadi sebesar 213.961.622.200.
\end{abstract}

\begin{abstract}
Karona Cahya Susena, Nurzam: The purpose of this study to determine the effectiveness of the trend of the motor vehicle tax revenue and income transfer tax DISPENDA motor vehicle in the province of Bengkulu. This study Brazilians Descriptive Analysis with sample used in this study is data Motor vehicle tax and motor vehicle title transfer fee, and Local Revenue Data Bengkulu province in 2010-2014. Least Square method used for forecasting.

Results of this study illustrate the effectiveness of the actual revenue and BBN-KB PKB. Equally terjadai in 2011 amounted to $122.26 \%$, and $129.42 \%$. PKB forecasting results in 2015 amounted to USD 194525355399 is forecast to increase in 2017 amounted to 230315333298 . BBN-KB forecasting results 2015 BBN-KB revenue of Rp 192990945600 is forecast to increase in 2017 amounted to 213961622200.
\end{abstract}

\section{Keyword: Trend Forecasting, Motor Vehicle Tax and Transfer Tax Motor Vehicle}

\section{PENDAHULUAN}

Dengan adanya otonomi daerah menjadikan Provinsi Bengkulu mencari sumbersumber penerimaan daerah yang biasa disebut Pendapatan Asli Daerah (PAD). PAD mempunyai salah satu komponen yaitu pajak daerah. Pajak daerah adalah pajak yang dipungut oleh pemerintah daerah baik daerah tingkat I (Pajak Provinsi) maupun daerah tingkat II (Pajak Kabupaten/ Kota) dan di guakan untuk membiayai rumah tangga daerah masing masing (Resmi, 2014:8).

Menurut Undang-undang No. 28 tahun 2009 tentang Pajak Daerah dan Restribusi Daerah, Pajak Daerah yang selanjutnya disebut adalah kontribusi wajib kepada Daerah yang terutang oleh orang pribadi atau badan yang bersifat memaksa berdasarkan Undang-Undang, dengan tidak mendapatkan imbalan secara langsung dan digunakan untuk keperluan Daerah bagi sebesar-besarnya kemakmuran rakyat.

Pajak bagi pemerintah daerah berperan sebagai sumber pendapatan (budgetary function) yang utama dan juga sebagai alat pengatur (regulatory function). Pajak sebagai salah satu sumber pendapatan daerah digunakan untuk membiayai pengeluaran-pengeluaran 
pemerintah. Melihat dari fenomena tersebut dapat diketahui pentingnya pajak bagi suatu daerah, terutama dalam menyokong pembangunan daerah itu sendiri dan merupakan pemasukan dana yang sangat potensial karena besarnya penerimaan pajak akan meningkat seiring laju pertumbuhan penduduk, perekonomian dan stabilitas politik.

Dinas Pendapatan Daerah (DISPENDA) Provinsi Bengkulu adalah instansi pemerintah yang memiliki tugas pokok antara lain untuk melaksanakan segala usaha kegiatan pemungutan, pengumpulan dan pemasukan pendapatan daerah kedalam kas daerah secara maksimum baik terhadap daerah yang ada maupun dengan penggalian sumber sumber pendapatan daerah berdasarkan kebijakan yang ditetapkan oleh Gubernur atau peraturan perundang-undangan yang berlaku.

Pajak Kendaraan Bermotor (PKB) dan Bea Balik Nama Kendaraan Bermotor (BBN-KB) Provinsi Bengkulu merupakan sumber pendapatan daerah yang terbesar dan selalu mengalami peningkatan dari tahun ke tahun. Data yang di peroleh ditunjukkan pada tabel 1. Dan tabel 2 Di bawah ini:

Tabel 1. Target dan Realisasi Pajak Kendaraan Bermotor (PKB) Provinsi Bengkulu Tahun 2010-2014

\begin{tabular}{|c|c|c|}
\hline Tahun & Target & Realisasi \\
\hline 2010 & 76.070 .321 .000 & 83.783 .056 .000 \\
\hline 2011 & 86.415 .257 .199 & 105.647 .588 .004 \\
2012 & 115.421 .852 .500 & 127.547 .813 .000 \\
\hline 2013 & 135.242 .059 .261 & 143.333 .492 .500 \\
\hline 2014 & 145.766 .827 .425 & 154.415 .048 .500 \\
\hline
\end{tabular}

Sumber: Dinas Pendapatan Daerah Provinsi Bengkulu, 2015

Tabel 2. Target dan Realisasi Bea Balik Nama Kendaraan Bermotor (BBN-KB) Provinsi Bengkulu Tahun 2010-2014

\begin{tabular}{|c|c|c|}
\hline Tahun & Target & Realisasi \\
\hline 2010 & 110.798 .668 .603 & 112.177 .688 .000 \\
\hline 2011 & 124.557 .311 .526 & 161.198 .838 .000 \\
\hline 2012 & 168.914 .311 .500 & 157.391 .381 .000 \\
\hline 2013 & 168.914 .311 .500 & 158.552 .513 .000 \\
\hline 2014 & 168.914 .311 .500 & 165.927 .542 .000 \\
\hline
\end{tabular}

Sumber: Dinas Pendapatan Daerah Provinsi Bengkulu, 2015

Dari tabel 1. Diatas dapat dilihat bahwa realisasi Pajak Kendaraan Bermotor (PKB) dari tahun 2010 sampai tahun 2014 selalu mengalami peningkatan. Dengan meningkatnya penerimaan Pajak Kendaraan Bermotor menunjukkan pemilikan kendaraan bermotor di Provinsi Bengkulu selalu meningkat dari tahun ke tahun. Melihat perkembangan pada tabel 2. Dari tahun ketahun secara rata-rata menunjukkan tidak tercapainya target penerimaan Bea Balik Nama Kendaraan Bermotor.

Data tahun 2010 - 2014 merupakan data yang perlu di lakukan perbaikan dimana kendaraan bermotor, mobil, truk yang masih belum terdata yang seharusnya menjadi objek pajak dan banyaknya kendaraan bermotor yang menetap di provinsi bengkulu dengan plat luar kota yang belum melakuan balik nama atau sebagai pendapatan pajak bea balik nama.

Peningkatan Pendapatan Asli Daerah (PAD) sangat tergantung dengan menggali potensi sumber-sumber pendapatan asli daerah. Oleh karena itu, ekstensifikasi dan intensifikasi sumber-sumber objek PAD menjadi sangat penting dalam upaya peningkatan pendapatan asli daerah.

Dalam rangka penyusunan APBD, DISPENDA Provinsi Bengkulu harus menghitung potensi sumber-sumber pendapatan pajak daerah. Salah satu sumber pendapatan daerah adalah Pajak Kendaraan Bermotor (PKB) dan Bea Balik Nama Kendaraan Bermotor (BBN-KB). Berdasarkan data tabel 1. Dan tabel 2. Perlu di lakukan kajian untuk mengetahui proyeksi 
pendapatan pajak daerah khususnya Pajak Kendaraan Bermotor (PKB) dan Bea Balik Nama Kendaraan Bermotor (BBN-KB) untuk 3 (Tiga) tahun kedepan yaitu tahun 2015-2017.

\section{LANDASAN TEORI}

Pajak

Pajak menurut Undang - Undang Nomor 16 Tahun 2009, Pasal 1 ayat (1) Pajak adalah kontribusi wajib kepada Negara yang terutang oleh orang pribadi ataubadan yang bersifat memaksa berdasarkan Undang-Undang dengan tidak mendapatkan imbalan secara langsung dan digunakan untuk keperluan Negara bagisebesar-besarnya kemakmuran rakyat.

Menurut Prof. Dr. Rochmat Sumitro, SH (Mardiasmo, 2013:1) bahwa pajak merupakan iuran rakyat pada kas negara berdasarkan Undang-Undang (yang dapat di paksakan) dengan tiada mendapat jasa timbal (kontraprestasi) yang langsung dapat di tunjukkan dan yang di gunakan untuk membayar pengeluaran umum. Pajak menurut S. I. Djajadinigrat (Resmi, 2014: 1) adalah sebagai suatu kewajiban menyerahkan sebagian dari kekayaan ke kas Negarayang disebabkan suatu keadaan, kejadian, dan perbuatan yang memberikan kedudukan tertentu, tetapi bukan sebagai hukuman, menurut peraturan yangditetapkan Pemerintah serta dapat dipaksakan tetapi tidak ada jasa timbal balik dari Negara secara langsung, untuk memelihara kesejahteraan secara umum. Pendapat lain tentang pengertian pajak di kemukakan oleh Dr. N. J. Fedelmann (Resmi, 2014: 2) menyatakan prestasi yang dipaksakan sepihak oleh dan terutang kepada penguasa (menurut norma-norma yang ditetapkannya secara umum), tanpa adanya kontraprestasi, dan semata-mata digunakan untuk menutup pengeluaran-pengeluaran umum. berikut:

Dari pengerian di atas ciri-ciri yang melekat pada pengertian pajak adalah sebagai

1. Pajak di pungut berdasarkan Undang-Undang

2. Jasa timbal tidak di tunjukkan secara langsung

3. Pajak dipungut oleh pemerintah,baik pemerintah pusat maupun pemerintah daerah.

4. Diperuntukkan bagi pengeluaran - pengeluaran pemerintah (jika surplus digunakan untuk public saving). (Susena, 2015:97).

\section{Pajak Daerah}

Pajak Daerah menurut Pasal 1 Undang-undang Nomor 28 Tahun 2009 menyatakan kontribusi wajib kepada Daerah yang terutang oleh orang pribadi atau badan yang bersifat memaksa berdasarkan Undang-Undang, dengan tidak mendapatkan imbalan secara langsung dan digunakan untuk keperluan Daerah bagi sebesar-besarnya kemakmuran rakyat.

Dengan demikian pajak daerah adalah iuran wajib pajak kepada daerah untuk membiayai pembangunan daerah. Pajak Daerah ditetapkan dengan undang-undang yang pelaksanaannya untuk di daerah diatur lebih lanjut dengan peraturan daerah. Pemerintah daerah dilarang melakukan pungutan selain pajak yang telah ditetapkan undang-undang (Pasal 2 Undang-Undang Nomor 28 Tahun 2009).

Pajak yang di kelola pemerintah daerah baik Provinsi maupun kabupaten/ kota dapat dilihat pada tabel 3. Dibawah ini: 
Tabel 3. Jenis-Jenis Pajak yang Dikelola Pemerintah Daerah

\begin{tabular}{|c|c|}
\hline Pajak Provinsi & Pajak Kabupaten/Kota \\
\hline $\begin{array}{l}\text { 1. Pajak Kendaraan Bermotor } \\
\text { 2. Bea Balik Nama Kendaraan } \\
\text { Bermotor } \\
\text { 3. Pajak Bahan Bakar Kendaraan } \\
\text { Bermotor } \\
\text { 4. Pajak Air Permukaan } \\
\text { 5. Pajak Rokok }\end{array}$ & 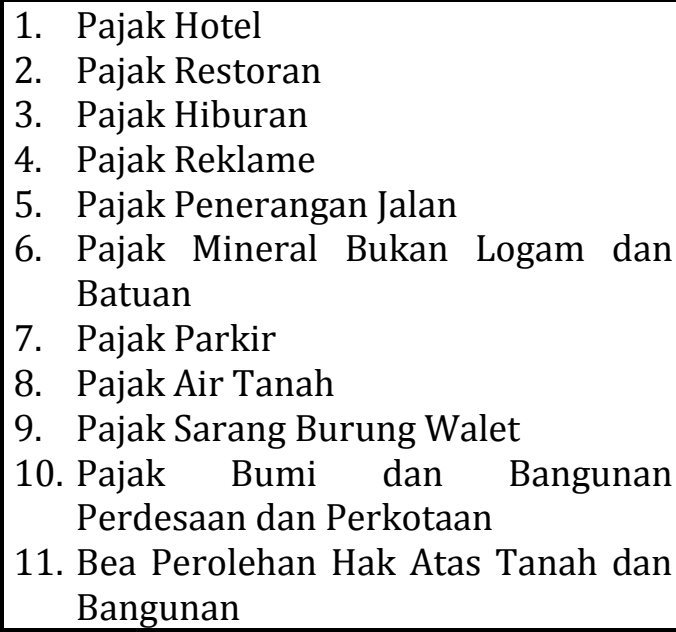 \\
\hline
\end{tabular}

Sumber: Undang-Undang No 28 Tahun 2009

\section{Pajak Provinsi}

Ada lima jenis pajak yang dikelola oleh provinsi yaitu Pajak Kendaraan Bermotor, Bea Balik Nama Kendaraan Bermotor, Pajak Bahan Bakar Kendaraan Bermotor, Pajak Air Permukaan dan Pajak Rokok.

1) Pajak Kendaraan Bermotor

Pajak Kendaraan Bermotor adalah pajak atas kepemilikan dan/atau penguasaan kendaraan bermotor. Kendaraan bermotor adalah semua kendaraan beroda beserta gandengannya yang digunakan di semua jenis jalan darat, dan digerakkan oleh peralatan teknik berupa motor atau peralatan lainnya yang berfungsi untuk mengubah suatu sumber daya energi tertentu menjadi tenaga gerak kendaraan bermotor yang bersangkutan, termasuk alat-alat berat dan alat-alat besar yang dalam operasinya menggunakan roda dan motor dan tidak melekat secara permanen serta kendaraan bermotor yang dioperasikan di air (Pasal 1 Undang-Undang Nomor 28 Tahun 2009).

2) Bea Balik Nama Kendaraan Bermotor

Bea Balik Nama Kendaraan Bermotor adalah pajak atas penyerahan hak milik kendaraan bermotor sebagai akibat perjanjian dua pihak atau perbuatan sepihak atau keadaan yang terjadi karena jual beli, tukar menukar, hibah, warisan, atau pemasukan ke dalam badan usaha (Pasal 1 Undang-Undang Nomor 28 Tahun 2009).

3) Pajak Bahan Bakar Kendaraan Bermotor

Pajak Bahan Bakar Kendaraan Bermotor adalah pajak atas penggunaan bahan bakar kendaraan bermotor. Bahan bakar kendaraan bermotor adalah semua jenis bahan bakar cair atau gas yang digunakan untuk kendaraan bermotor (Pasal 1 Undang-Undang Nomor 28 Tahun 2009). Tarif Pajak Bahan Bakar Kendaraan Bermotor ditetapkan paling tinggi sebesar 10\% (sepuluh persen). Khusus tarif Pajak Bahan Bakar Kendaraan Bermotor untuk bahan bakar kendaraan umum dapat ditetapkan paling sedikit 50\% (lima puluh persen) lebih rendah dari tarif Pajak Bahan Bakar Kendaraan Bermotor untuk kendaraan pribadi (Pasal 19 Undang-Undang Nomor 28 Tahun 2009). 
4) Pajak Air Permukaan

Menurut Undang-Undang Nomor 28 Tahun 2009 Tentang Pajak Daerah dan Retribusi Daerah, Pajak Air Permukaan adalah pajak atas pengambilan dan/atau pemanfaatan air permukaan. Air permukaan adalah semua air yang terdapat pada permukaan tanah, tidak termasuk air laut, baik yang berada di laut maupun di darat. Tarif Pajak Air Permukaan ditetapkan paling tinggi sebesar 10\% (Pasal 24 Undang-Undang nomor 28 Tahun 2009).

5) Pajak Rokok

Menurut Undang-Undang Nomor 28 Tahun 2009 Tentang Pajak Daerah dan Retribusi Daerah, Pajak Rokok adalah pungutan atas cukai rokok yang dipungut oleh Pemerintah. Tarif Pajak Rokok ditetapkan sebesar 10\% (sepuluh persen) dari cukai rokok. Pajak Rokok dikenakan atas cukai rokok yang ditetapkan oleh Pemerintah (Pasal 29 Undang-Undang Nomor 28 Tahun 2009).

Penerimaan pajak rokok, baik bagian Provinsi maupun bagian Kabupaten/kota, dialokasikan paling sedikit 50\% untuk mendanai pelayanan kesehatan masyarakat dan penegakan hukum oleh aparat yang berwenang ( Pasal 31 Undang-Undang Nomor 28 Tahun 2009).

\section{Pajak Kendaraan Bermotor}

Pajak Kendaraan Bermotor Semula sesuai dengan UU No. 18 tahun 1997 ditetapkan Pajak Kendaraan Bermotor, dimana pajak atas PKB (Pajak Kendaraan Bermotor) \& PKAA (Pajak Kendaraan Diatas Air) dicakupkan. Seiring dengan perubahan UU No. 18 tahun 1997 menjadi UU No. 34 tahun 2000, terminologi kendaraan bermotor diperluas dan dilakukan pemisahan secara tegas menjadi Kendaraan Bermotor dan di Kendaraan Atas Air. Hal ini membuat Pajak Kendaraan Bermotor diperluas menjadi PKB \& PKAA. Dalam praktiknya jenis pajak ini sering di bagi atas 2, yaitu PKB dan PKAA. Hal ini wajar saja mengingat kendaraan bermotor pada dasarnya berbeda dengan kendaraan di atas air. Pengenaan PKB \& PKAA tidak mutlak ada pada seluruh daerah provinsi di indonesia. Hal ini berkaitan dengan kewenangan yang diberikan kepada pemerintah provinsi untuk mengenakan atau tidak mengenakan suatu jenis pajak provinsi. Untuk dapat dipungut pada suatu daerah provinsi pemerintah daerah harus terlebih dahulu menerbitkan Peraturan Daerah tentang PKB, yang akan menjadi landasan hukum operasional dalam teknis pelaksanaan pengenaan dan pemungutan PKB \& PKAA didaerah provinsi yang bersangkutan. Pemerintah provinsi diberi kebebasan untuk menetapkan apakah PKB ditetapkan dalam satu peraturan daerah atau ditetapkan dalam dua peraturan daerah terpisah.

Pajak Kendaraan Bermotor (PKB) adalah pajak atas kepemilikan atau penguasaan kendaraan bermotor (kendaraan beroda dua atau lebih beserta gandengannya yang digunakan di semua jenis jalan darat dan digerakkan oleh peralatan teknik berupa motor atau peraltan lainnya yang berfungsi untuk mengubah suatu sumber daya energi tertentu menjadi tenaga gerak kendaraan bermotor yang bersangkutan, termasuk alat-alat besar yang bergerak). diatur dalam :

Dasar Hukum Pajak Kendaraan Bermotor Dasar hukum pajak kendaraan bermotor

1. Undang-Undang Nomor 34 tahun 2000 yang merupakan perubahan atas Undang-Undang Nomor 18 tahun 1997 tentang Pajak Daerah dan Retribusi Daerah.

2. Peraturan Pemerintah Nomor 65 tahun 2001 tentang Pajak Daerah.

3. Peraturan daerah provinsi yang mengatur tentang PKB. Peraturan daerah ini dapat menyatu, yaitu satu peraturan daerah untuk PKB, tetapi dapat juga dibuat secara terpisah misalnya Peraturan Daerah tentang PKB.

4. Peraturan Menteri Dalam Negeri Nomor 2 tahun 2006 tentang Perhitungan Dasar Pengenanan Pajak Kendaraan Bermotor dan Bea Balik Nama Kendaraan Bermotor Tahun 2006. 
5. Peraturan Gubernur yang mengatur tentang PKB sebagai aturan pelaksanaan peraturan daerah tentang PKB pada provinsi yang dimaksud.

Objek dan Wajib Pajak Kendaraan Bermotor Objek Pajak Kendaraan Bermotor adalah kepemilikan atau penguasaa kendaraan bermotor yang digunakan di semua jenis jalan darat seperti kawasan : 1. Bandara 2. Pelabuhan laut 3. Perkebunan 4. Kehutanan 5. Pertanian 6. Pertambangan 7. Industri 8. Perdagangan 9. Sarana olah raga dan rekreasi

Wajib Pajak adalah orang pribadi atau badan yang memiliki kendaraan bermotor, jika wajib pajak merupakan badan maka kewajiban perpajakannya diwakili oleh pengurus atau kuasa hukum badan tersebut. Dengan demikian, pada PKB subjek pajak sama dengan wajib pajak, yaitu orang pribadi atau badan yang memiliki atau menguasai kendaraan bermotor. Tarif Pajak Kendaraan Bermotor pribadi menurut Pasal 6 Undang-Undang Nomor 28 Tahun 2009 Tentang Pajak Daerah dan Retribusi Daerah ditetapkan sebagai berikut :

a. Untuk kepemilikan kendaraan bermotor pertama paling rendah sebesar $1 \%$ (satu persen) dan paling tinggi sebesar 2\% (dua persen);

b. Untuk kepemilikan kendaraan bermotor kedua dan seterusnya tarif dapat ditetapkan secara progresif paling rendah sebesar 2\% (dua persen) dan paling tinggi sebesar 10\% (sepuluh persen).

Sedangkan tarif Pajak Kendaraan Bermotor angkutan umum, ambulans, pemadam kebakaran, sosial keagamaan, lembaga sosial dan keagamaan, Pemerintah/TNI/POLRI, Pemerintah Daerah, dan kendaraan lain yang ditetapkan dengan Peraturan Daerah, ditetapkan paling rendah sebesar 0,5\% (nol koma lima persen) dan paling tinggi sebesar 1\% (satu persen). Kemudian Tarif Pajak Kendaraan Bermotor alat-alat berat dan alat-alat besar ditetapkan paling rendah sebesar 0,1\% (nol koma satu persen) dan paling tinggi sebesar 0,2\% (nol koma dua persen).

\section{Bea Balik Nama Kendaraan Bermotor}

Bea Balik Nama Kendaraan Bermotor (BBN-KB) dalam adalah pajak atas penyerahan hak milik kendaraan bermotor sebagai akibat perjanjian dua belah pihak atau perbuuatan sepihak atau keadaan yang terjadi karena jual beli, tukar menukar, hibah, warisan, atau pemasukan ke badan usaha. (Peraturan Menteri Dalam Negeri Republik Indonesia Nomor 101 Tahun 2014).

Obyek BBN-KB Adalah penyerahan Kendaraan Bermotor, yaitu pengalihan hak milik Kendaraan Bermotor sebagai akibat perjanjian dua pihak atau perbuatan sepihak atau keadaan yang terjadi karena jual beli, tukar menukar, hibah termasuk hibah wasiat dan hadiah, warisan, atau pemasukan ke dalam Badan Usaha. sedangkan Subyek BBN-KB Adalah orang pribadi atau badan yang menerima penyerahan Kendaraan Bermotor (KBM).

Menurut Pasal 12 Undang-Undang Nomor 28 Tahun 2009 Tentang Pajak Daerah dan Retribusi Daerah tarif Bea Balik Nama Kendaraan Bermotor ditetapkan paling tinggi masing-masing sebagai berikut :

a. Penyerahan pertama sebesar $20 \%$ (dua puluh persen) dan

b. Penyerahan kedua dan seterusnya sebesar $1 \%$ (satu persen).

Khusus untuk kendaraan bermotor alat-alat berat dan alat-alat besar yang tidak menggunakan jalan umum tarif pajak ditetapkan paling tinggi masing-masing sebagai berikut:

a. Penyerahan pertama sebesar $0,75 \%$ (nol koma tujuh puluh lima persen);

b. Penyerahan kedua dan seterusnya sebesar $0,075 \%$ (nol koma nol tujuh puluh lima persen). 


\section{Kerangka Analisis}

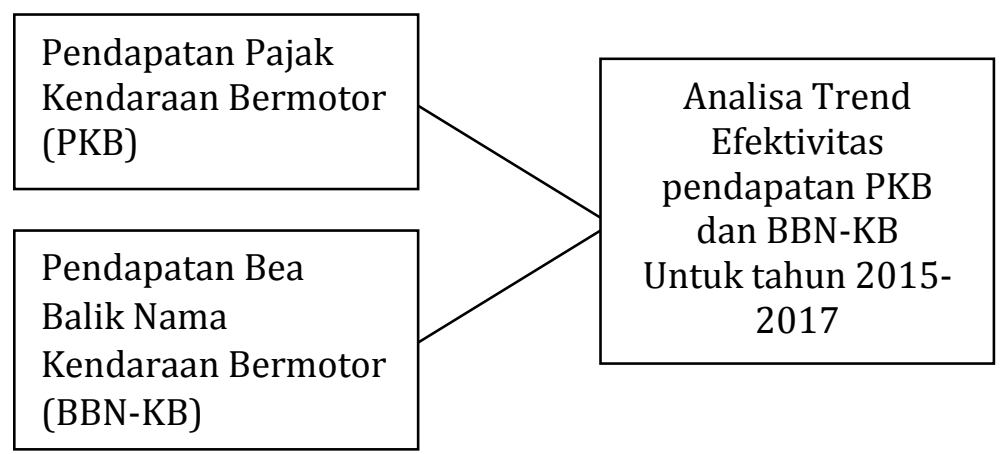

Gambar 1. Kerangka Analisis

\section{METODE PENELITIAN}

Penelitian ini merupakan penelitian Analisis Deskriptif maksudnya memberikan gambaran tentang perkembangan komponen Pajak Daerah di Provinsi Bengkulu studi dari waktu ke waktu menurut jenis komponen dari pos Pajak Daerah serta gambaran taget dan realisasinya. Sampel yang digunakan dalam penelitian ini adalah Data Pajak kendaraan bermotor dan bea balik nama kendaraan bermotor, dan Data PAD Provinsi Bengkulu tahun 2010-2014.

Metode Least Square digunakan untuk metode forecast dimana teknik statistika dan matematis dipakai sebagai alat primer dalam penyusunan peramalan, sedangkan pendapat dipakai sebagai pelengkap.

Dengan persamaan:

$$
\mathrm{Y}=\mathrm{a}+\mathrm{bx}
$$

$\operatorname{dimana}: \mathrm{a}=\sum \mathrm{y} / \mathrm{n} \quad \mathrm{b}=\sum \mathrm{y} / \sum \mathrm{x}^{2}$

Keterangan:

$\mathrm{Y} \quad=$ Variabel yang akan diramalkan

a $\quad=$ Konstanta.

$\mathrm{b} \quad=$ Koefisien Korelasi.

$\mathrm{x} \quad=$ Unit waktu/ periode. yang dapat dinyatakan dalam tahun

Efektivitas merupakan tingkat capaian antara realisasi penerimaan PKB dan BBNKB yang menunjukkan apakah besarnya realisasi penerimaan PKB dan BBNKB sesuai dengan targetnya. Untuk mengukur efektivitas realisasi pendapatan PKB dan BBN-KB dari target yang diberikan maka dapat digunakan perhitungan sebagai berikut:

\section{Efektivitas $=\frac{\text { Realissasi Penerimaan PKB dan BBN-KB }}{\text { Target Penerimaan PKB dan BBN-KB }} \times 100 \%$}


Untuk mengukur tingkat efektivitas dapat memberikan peringkat dengan menggunakan metode skala peringkat (Siagian, 2014:234). Skala peringkat tersebut adalah sebagai berikut:

$\begin{array}{ll}90-100 & =\text { Sangat Efektif } \\ 80-89 & =\text { Efektif } \\ 70-79 & =\text { Cukup Efektif } \\ 60-69 & =\text { Kurang Efektif } \\ 0-59 & =\text { Tidak Efektif }\end{array}$

\section{HASIL DAN PEMBAHASAN}

Perkembangan penerimaan Pajak Kendaraa Bermotor (PKB) dan Bea Balik Nama Kendaraan Bermotor (BBN-KB) dapat di lihat pada tabel 4. Dan 5 berikut ini:

\section{Tabel 4. Penerimaan Pajak Kendaraan Bermotor (PKB)} Provinsi Bengkulu Tahun 2010-2014

\begin{tabular}{|c|c|c|c|c|}
\hline Tahun & Target & Realisasi & $\%$ & Keterangan \\
\hline 2010 & 76.070 .321 .000 & 83.783 .056 .000 & 110,14 & Over Target \\
\hline 2011 & 86.415 .257 .199 & 105.647 .588 .004 & 122,26 & Over Target \\
\hline 2012 & 115.421 .852 .500 & 127.547 .813 .000 & 110,51 & Over Target \\
\hline 2013 & 135.242 .059 .261 & 143.333 .492 .500 & 105,98 & Over Target \\
\hline 2014 & 145.766 .827 .425 & 154.415 .048 .500 & 105,93 & Over Target \\
\hline
\end{tabular}

Sumber: Dinas Pendapatan Daerah Provinsi Bengkulu, 2015

Tabel 5. Penerimaan Bea Balik Nama Kendaraan Bermotor (BBN-KB) Provinsi Bengkulu Tahun 2010-2014

\begin{tabular}{|c|c|c|c|c|}
\hline Tahun & Target & Realisasi & $\%$ & Keterangan \\
\hline 2010 & 110.798 .668 .603 & 112.177 .688 .000 & 101,24 & Over Target \\
\hline 2011 & 124.557 .311 .526 & 161.198 .838 .000 & 129,42 & Over Target \\
\hline 2012 & 168.914 .311 .500 & 157.391 .381 .000 & 93,18 & Under Target \\
\hline 2013 & 168.914 .311 .500 & 158.552 .513 .000 & 93,87 & Under Target \\
\hline 2014 & 168.914 .311 .500 & 165.927 .542 .000 & 98,23 & Under Target \\
\hline
\end{tabular}

Sumber: Dinas Pendapatan Daerah Provinsi Bengkulu, 2015

\section{Pembahasan \\ Trend Peramalan}

Proyeksi penerimaan pajak Pajak Kendaraan Bermotor (PKB) Provinsi Bengkulu bertujuan untuk mengetahui gambaran penerimaan pajak Pajak Kendaraan Bermotor (PKB) Provinsi Bengkulu. Data proyeksi dapat dijadikan sebagai acuan atau pedoman oleh pemerintah Provinsi Bengkulu melalui DISPENDA dalam pelaksanaan pemungutan pajak PKB tahun 20152017. Perhitungan trend Pajak Kendaraan Bermotor (PKB) Provinsi Bengkulu disajikan dalam tabel 6. 
Tabel 6. Perhitungan Trend Pajak Kendaraan Bermotor (PKB) Provinsi Bengkulu Berdasarkan Realisasi Tahun 2010-2014

\begin{tabular}{|c|c|c|c|c|c|}
\hline Tahun & $\mathbf{X}$ & $\begin{array}{c}\text { Realisasi PKB (Rp) } \\
\mathbf{Y}\end{array}$ & $\mathbf{X}$ & $\mathbf{X}^{2}$ & $\mathbf{X Y}$ \\
\hline 2010 & 0 & 83.783 .056 .000 & 0 & 7.019 .600 .472 .699 .140 .000 .000 & - \\
\hline 2011 & 1 & 105.647 .588 .004 & 1 & 11.161 .412 .851 .062 .900 .000 .000 & 105.647 .588 .004 \\
\hline 2012 & 2 & 127.547 .813 .000 & 4 & 16.268 .444 .601 .083 .000 .000 .000 & 255.095 .626 .000 \\
\hline 2013 & 3 & 143.333 .492 .500 & 9 & 20.544 .490 .072 .247 .600 .000 .000 & 430.000 .477 .500 \\
\hline 2014 & 4 & 154.415 .048 .500 & 16 & 23.844 .007 .203 .257 .400 .000 .000 & 617.660 .194 .000 \\
\hline Jumlah & 10 & 614.726 .998 .004 & 30 & 78.837 .955 .200 .349 .900 .000 .000 & 1.408 .403 .885 .504 \\
\hline
\end{tabular}

Sumber: DPPKA Kota Bengkulu, 2015 (diolah)

Menggunakan perhitungan trend dengan metode last Square maka dapat di peroleh persamaan $Y=8.715 .5421 .701,6+17.894 .988 .949,6 \mathrm{X}$. Dengan menggunakan persamaan tersebut, diperoleh proyeksi penerimaan Pajak Kendaraan Bermotor (PKB) Provinsi Bengkulu untuk tahun 2015 sampai dengan 2017, sebagai berikut:

Tabel 7. Proyeksi Penerimaan Pajak Kendaraan Bermotor (PKB) Provinsi Bengkulu Tahun 2015-2017

\begin{tabular}{|c|c|c|}
\hline No & Tahun & Proyeksi Pajak Hotel (Rp) \\
\hline 1 & 2015 & 194.525 .355 .399 \\
\hline 2 & 2016 & 212.420 .344 .349 \\
\hline 3 & 2017 & 230.315 .333 .298 \\
\hline
\end{tabular}

Sumber: Data Diolah, 2015

Tabel 7. menunjukkan proyeksi penerimaan Pajak Kendaraan Bermotor (PKB) Provinsi Bengkulu tahun 2015-2017. Tahun 2015 penerimaan Pajak Kendaraan Bermotor (PKB) Provinsi Bengkulu diperkirakan mencapai Rp 194.525.355.399atau mengalami pertumbuhan sebesar 25,98\% dari tahun sebelumnya. Selanjutnya pada tahun 2016, diproyeksikan penerimaan Pajak Kendaraan Bermotor (PKB) Provinsi Bengkulu sebesar Rp 212.420.344.349sedangkan tahun 2017 diproyeksikan sebesar Rp 230.315.333.298.

Perhitungan trend Bea Balik Nama Kendaraan Bermotor (BBN-KB) Provinsi Bengkulu disajikan dalam tabel 8. Digunakan untuk proyeksi penerimaan Bea Balik Nama Kendaraan Bermotor (BBN-KB) Provinsi Bengkulu dan untuk mengetahui gambaran penerimaan pajak Pajak Kendaraan Bermotor (PKB) Provinsi Bengkulu pada tahun 2015-2017. 
Tabel 8. Perhitungan Trend Bea Balik Nama Kendaraan Bermotor (BBN-KB) Provinsi Bengkulu Berdasarkan Realisasi Tahun 2010-2014

\begin{tabular}{|c|c|c|c|c|c|}
\hline Tahun & $\mathbf{X}$ & $\begin{array}{c}\text { Realisasi PKB (Rp) } \\
\mathbf{Y}\end{array}$ & $\mathbf{X}^{2}$ & $\mathbf{Y}$ & \multicolumn{1}{|c|}{$\mathbf{Y Y}$} \\
\hline 2010 & 0 & 112.177 .688 .000 & 0 & 12.583 .833 .685 .025 .300 .000 .000 & - \\
\hline 2011 & 1 & 161.198 .838 .000 & 1 & 25.985 .065 .372 .550 .200 .000 .000 & 161.198 .838 .000 \\
\hline 2012 & 2 & 157.391 .381 .000 & 4 & 24.772 .046 .813 .087 .200 .000 .000 & 314.782 .762 .000 \\
\hline 2013 & 3 & 158.552 .513 .000 & 9 & 25.138 .899 .378 .615 .200 .000 .000 & 475.657 .539 .000 \\
\hline 2014 & 4 & 165.927 .542 .000 & 16 & 27.531 .949 .194 .161 .800 .000 .000 & 663.710 .168 .000 \\
\hline Jumlah & 10 & 755.247 .962 .000 & 30 & 116.011 .794 .443 .440 .000 .000 .000 & 1.615 .349 .307 .000 \\
\hline
\end{tabular}

Sumber: DPPKA Kota Bengkulu, 2015 (diolah)

Menggunakan perhitungan trend dengan metode last Square maka dapat di peroleh persamaan $\mathrm{Y}=130.078 .915 .800+10.485 .338 .300 X$. Dengan menggunakan persamaan tersebut, diperoleh proyeksi penerimaan Bea Balik Nama Kendaraan Bermotor (BBN-KB) Provinsi Bengkulu untuk tahun 2015 sampai dengan 2017, sebagai berikut:

Tabel 9. Proyeksi Penerimaan Bea Balik Nama Kendaraan Bermotor (BBN-KB) Provinsi Bengkulu Tahun 2015-2017

\begin{tabular}{|c|c|c|}
\hline No & Tahun & Proyeksi Pajak Hotel (Rp) \\
\hline 1 & 2015 & 192.990 .945 .600 \\
\hline 2 & 2016 & 203.476 .283 .900 \\
\hline 3 & 2017 & 213.961 .622 .200 \\
\hline
\end{tabular}

Sumber: Data Diolah, 2015

Tabel 9. menunjukkan proyeksi penerimaan Bea Balik Nama Kendaraan Bermotor (BBN-KB) Provinsi Bengkulu tahun 2015-2017. Tahun 2015 penerimaan Bea Balik Nama Kendaraan Bermotor (BBN-KB) Provinsi Bengkulu diperkirakan mencapai Rp 192.990.945.600 atau mengalami pertumbuhan sebesar 16,31\% dari tahun sebelumnya. Selanjutnya pada tahun 2016, diproyeksikan penerimaan Bea Balik Nama Kendaraan Bermotor (BBN-KB) Provinsi Bengkulu sebesar Rp 203.476.283.900 sedangkan tahun 2017 diproyeksikan sebesar Rp 213.961.622.200

\section{Efektivitas dalam Pemungutan PKB dan BBN KB}

Dari data tahun 2010-2014 menunjukkan perkembangan realisasi penerimaan pajak kendaraan Bermotor, tingkat efektivitas penerimaannya sudah tergolong efektif dikarenakan realisasi penerimaan yang melebihi target, maka dapat disimpulkan bahwa prosedur pelaksanaan pemungutan pajak kendaraan bermotor. untuk perkembangan realisasi penerimaan Bea Balik Nama Kendaraan Bermotor walaupun tidak mencaai taget atau meskipun disetiap tahun dalam penerimaannya mengalami peningkatan dan penurunan tetapi berjalan efektif.

Realisasi yang sudah melebihi target atau terjadi kenaikan dalam realisasi penerimaannya, disebabkan karena adanya pembayaran tunggakan pajak pada tahun sebelumnya yang meningkatkan penerimaan PKB dan BBNKB. Hal ini dapat dikatakan efektif dan efisien karena keberhasilan DISPENDA dalam mencapai hasil yang ditargetkan dengan 
dilaksanakannya pemungutan Pajak Kendaraan Bermotor dan Bea Balik Nama Kendaraan Bermotor pada setiap UPTD Dispenda yang tersebar di 9 (sembilan) kabupaten dan 1 (Satu) Kota, sehingga dapat mempermudah wajib pajak dalam membayar pajak berdasarkan prosedur atau mekanisme yang diterapkan .

\section{Kesimpulan}

1. Trend Proyeksi untuk 3 (tiga) tahun mendatang pad tahun 2015 penerimaan Pajak Kendaraan Bermotor (PKB) Provinsi Bengkulu diperkirakan mencapai Rp 194.525.355.399atau mengalami pertumbuhan sebesar 25,98\% dari tahun sebelumnya. Selanjutnya pada tahun 2016, diproyeksikan penerimaan Pajak Kendaraan Bermotor (PKB) Provinsi Bengkulu sebesar Rp 212.420.344.349sedangkan tahun 2017 diproyeksikan sebesar Rp 230.315.333.298.

2. Proyeksi penerimaan Bea Balik Nama Kendaraan Bermotor (BBN-KB) Provinsi Bengkulu tahun 2015-2017. Tahun 2015 penerimaan Bea Balik Nama Kendaraan Bermotor (BBN-KB) Provinsi Bengkulu diperkirakan mencapai Rp 192.990 .945 .600 atau mengalami pertumbuhan sebesar 16,31\% dari tahun sebelumnya. Selanjutnya pada tahun 2016, diproyeksikan penerimaan Bea Balik Nama Kendaraan Bermotor (BBN-KB) Provinsi Bengkulu sebesar Rp 203.476.283.900 sedangkan tahun 2017 diproyeksikan sebesar Rp 213.961.622.200

3. Tingkat efektivitas penerimaan Pajak Kendaraan Bermotor dan Bea Balik Nama Kendaraan Bermotor dapat dikatakan efektif. Hal ini terlihat dari rasio efektivitas penerimaan Pajak Kendaraan Bemotor dan Bea Balik Nama Kendaraan Bermotor berdasarkan hasil analisis perhitungan tingkat efektivitas selama tahun 2010-2014 untuk tingkat efektivitas yang paling tinggi yaitu tahun 2011 masing-masing sebesar 122,26\%, dan 129,42\%.

\section{Saran}

1. Proses pembayaran yang mudah, tempat UPPT di daerah yang strategis serta pelayanan dari berbagai pihak di tingkatkan sehingga memberikan rasa nyaman bagi wajib pajak dalam melakukan pembayaran.

2. Pihak DISPENDA, Jasa Raharja dan pihak kepolisian hendaknya lebih memperhatikan dalam penertiban wajib pajak yang belum membayar PKB dan BBNKB dengan melakukan pendataan ulang jumlah kendaraan bermotor yang ada dan mendatangi rumah wajib pajak, mengadakan razia kendaraan bermotor di semua UPPT yang tersebar di Kabupaten/Kota yang ada di Provinsi Bengkulu.

\section{DAFTAR PUSTAKA}

Eryandi, Gusti, 2011, Analisis Efektivitas Pemungutan Pajak Kendaraan Bermotor Dan Bea Balik Nama Kendaraan Bermotor Dalam Meningkatkan Pendapatan Asli Daerah (PAD) Di Provinsi Bengkulu, Jurnal Ekonomi Dan Perencanaan Pembangunan Universitas Bengkulu, Vol. 4 NO. 02 Juli - Desember 2011

Mardiasmo, 2013, Perpajakan. Edisi Revisi. Yogyakarta. Penerbit Andi

Peraturan Daerah Provinsi Bengkulu Nomor 6 Tahun 2014 Tentang Pajak Daerah Provinsi Bengkulu

Peraturan Menteri dalam Negeri Republik Indonesia Nomor 101 Tahun 2014 tentang Perhitungan Dasar Pengenaan Pajak Kendaraan Bermotor Dan Bea Balik Nama Kendaraan Bermotor Tahun 2015 
Resmi, Siti, 2014, Perpajakan: Teori Dan Kasus, Edisi 8, Buku 1, Salemba Empat, Jakarta

Undang-undang No. 28 tahun 2009 tentang Pajak Daerah dan Restribusi Daerah.

Siagian, Sondang P. 2014. Manajemen Sumber Daya Manusia, Bumi Aksara, Jakarta.

Susena, C., Karona, 2015, Potensi Penerimaan Pajak Bumi Dan Bangunan Di Kota Bengkulu, Jurnal Ilmiah Ekonomi dan Bisnis "Ekombis Review" Universitas Dehasen Bengkulu, Volume 3 Nomor 1, Januari 2015 